\title{
Interrelationships of bacteria, meiofauna and macrofauna in a Mediterranean sedimentary beach (Maremma Park, NW Italy)
}

\author{
Nafsika Papageorgiou - Mariapaola Moreno • \\ Valentina Marin - Susanna Baiardo - Christos Arvanitidis • \\ Mauro Fabiano · Anastasios Eleftheriou
}

Received: 2 February 2006/Revised: 24 October 2006/ Accepted: 24 October 2006/Published online: 21 December 2006

(C) Springer-Verlag and AWI 2006

\begin{abstract}
Collelungo beach (Maremma Park, NW Italy), was sampled quantitatively for macrofauna, meiofauna and bacteria in May 2003; several physicochemical variables and variables associated with food availability and sediment structure were also measured. Replicated samples were collected from three sites representing natural conditions, an erosion regime, and the influence of the Ombrone River, respectively, as well as from four stations each located in the surf and sublittoral zones. Both uni- and multivariate techniques were used to assess the benthic community structure and the associated environmental variables. Different diversity indices revealed no pattern; in contrast, multivariate techniques applied on the macrobenthic fauna and the polychaete taxocommunity distinguished between the sites located in natural and eroding conditions from the one located nearby the discharges of the Ombrone river. The community patterns deriving from meio- and macrofauna are clearly divergent. The overall benthic faunal community appears to be influenced by both groups of organisms. The patterns of the meio- and macrofaunal communities seem to be affected synergistically by a
\end{abstract}

Communicated by H.-D. Franke.

N. Papageorgiou · C. Arvanitidis $(\bowtie)$.

A. Eleftheriou

Institute of Marine Biology and Genetics,

Hellenic Centre for Marine Research, Heraklion,

71003 Crete, Greece

e-mail: arvanitidis@her.hcmr.gr

M. Moreno · V. Marin · S. Baiardo · M. Fabiano Department of Study of the Territory and its Resources, University of Genoa, C.so Europa 26, 16132 Genoa, Italy number of environmental variables, in accordance with the multicausal environmental severity hypothesis. Meiofaunal patterns are more often correlated with bacteria and the protein concentration than are macrofaunal patterns, indicating a potential utilization of bacteria as a food source by the meiofaunal organisms. Total bacterial numbers are associated with the macrofaunal pattern under the erosion regime, probably as a consequence of competition for food between macrofauna and meiofauna.

Keywords Meiobenthos - Macrobenthos - Bacteria Sandy beaches

\section{Introduction}

Sandy beach communities are subjected to a variety of physical and biological disturbances, which make them one of the most dynamic and challenging natural environments. Most microtidal beaches change continuously their morphological and dynamic state, and thus their major community structure on a local scale (Turner et al. 1995). Community structure and the function of benthic organisms, ranging from bacteria to macrofauna, seem to be affected by environmental changes and the resulting morphodynamic gradient (Koop and Griffiths 1982; Albertelli et al. 1999; Incera et al. 2003). The structure and function of the benthic components play a very important role in the biochemical and metabolic processes of the sediment with important implications for the carbon cycle and the food web (Fabiano et al. 2004). A large part of these processes is carried out through the bacterial metabolism, which utilize the carbon in the detritus food chain. 
However, the role of bacteria as food source for the meio- and macrofauna is still not clear. According to Sundbaeck et al. (1996) the meiofaunal grazing is controlled by primary producers such as microalgae, but when these sources are in short supply, bacteria represent a readily available food source. Furthermore, meiofauna may compete with macrofauna for the same food sources (Higgins and Thiel 1988) or may be utilized as a food source by macrofauna.

Considerable information is available on the three benthic groups (bacteria, macro- and meiofauna) and their function in beach benthic ecosystems. However, studies on the ecological importance of these three components are still scarce (Koop and Griffiths 1982; Novitsky and Macsween 1989; Sundbaeck et al. 1996; Albertelli et al. 1999; Jedrzejczak 2002; Fabiano et al. 2004; Kotwicki et al. 2005; Moreno et al. 2005a,b). Moreover, datasets deriving from sampling activities simultaneously targeted at the afore-mentioned benthic components are very rare, especially for the Mediterranean Sea.

In the present study, benthic bacteria, meio- and macrofauna were collected simultaneously along transects in three sites of different geomorphological characteristics in the Regional Natural Park of Maremma beach (Collelungo beach).

The objectives of the study were (1) to explore to what extent community patterns deriving from both meio- and macrofauna are convergent, and (2) to test whether the bacterial community plays a key role for the meio- and macrofaunal assemblages of Mediterranean microtidal sandy beaches.

\section{Materials and methods}

\section{Study area}

The study was carried out at Collelungo sandy beach in the Maremma Regional Natural Park, situated on the northwest coast of Italy-Tuscany $\left(42^{\circ} 37^{\prime} 55^{\prime \prime} \mathrm{N}\right.$, $\left.11^{\circ} 04^{\prime} 57^{\prime \prime} \mathrm{E}\right)$ (Fig. 1). Collelungo sandy beach is about $7 \mathrm{~km}$ long, situated between the Ombrone River and the rocky shores of the Uccellina mountains (Marques et al. 2003). It is considered an exposed microtidal sandy beach (exposure rate 12, mean tidal range 20$30 \mathrm{~cm}$ ) with a very shallow slope (1\%) (Marques et al. 2003; Moreno et al. 2005b).

Over the past 25 years, the coastline profile has been modified a good deal in relation to the decrease of sediment transportation by the Ombrone River. This has caused beach erosion at sites near the mouth of the river and accretion at Collelungo.
The Collelungo beach was sampled in May 2003 at three sites (Mar 1-3) differing in geomorphological conditions: (1) at the site Mar 1 the conditions are considered representative of a natural Mediterranean sandy beach; (2) natural erosion is recorded in Mar 2 site; (3) sediment deposition due to discharges of the Ombrone River is documented for the Mar 3 site (Marques et al. 2003).

\section{Sampling}

\section{Macrofauna}

At each site, macrofauna was sampled along three parallel transects, spaced $1 \mathrm{~m}$ apart from each other. At each transect, Stations 1 and 3 were situated at $1 \mathrm{~m}$ distance above and below the water line, respectively; Station 2 was on the water line, and Station 4 was located in the sublittoral zone at $1 \mathrm{~m}$ depth. Samples were collected with cylindrical corers of $9.4 \mathrm{~cm}$ inner diameter (two corers were used for every replicate), penetrating $25 \mathrm{~cm}$ deep into the substrate. Sediments were sieved through a $0.5 \mathrm{~mm}$ mesh and afterwards the animals were fixed in a $5 \%$ formaline solution, buffered with seawater.

\section{Meiofauna}

Samples were collected with three cylindrical corers of $3.6 \mathrm{~cm}$ inner diameter, penetrating $10 \mathrm{~cm}$ deep into the substrate. Sediment samples were fixed with $4 \%$ buffered formaldehyde in filtered seawater. In the laboratory, all meiofaunal samples were rinsed with a gentle jet of freshwater over a $1 \mathrm{~mm}$ sieve to remove the macrofauna, decanted over a $38 \mu \mathrm{m}$ sieve $10 \times$,

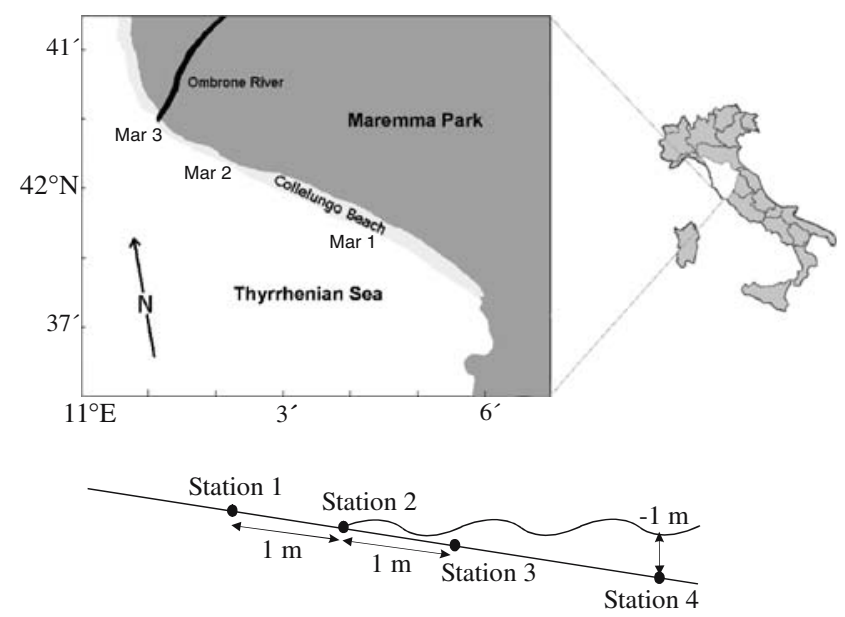

Fig. 1 Map of the study sites (Mar 1-3) at Collelungo beach along with the position of the sampling stations (Stations 1-4) relative to water line 
centrifuged $3 \times$ with Ludox HS40 (specific density 1.18; Heip et al. 1985) and stained with Rose Bengal. Meiofauna was counted and identified at the level of major taxa for all samples and layers, using a stereomicroscope, and density was recalculated as abundance $\times 10 \mathrm{~cm}^{-2}$.

\section{Bacteria}

For microbial analyses, samples were collected using sterile syringes, fixed with $2 \%$ prefiltered and sterilized formalin solution and stored at $4{ }^{\circ} \mathrm{C}$.

Samples were sonicated three times (Sonifier Labor 2000, $195 \mathrm{~W}$ for $1 \mathrm{~min}$ ). Subsamples were diluted in relation to cellular density. Portions of subsamples were withdrawn and stained for 5 min with Acridine Orange and filtered (Black Nucleopore $0.2 \mu \mathrm{m}$ ). Ten to twenty randomly chosen grids on each duplicate filter, per sample, were counted with epifluorescence microscopy (Zeiss Universal Microscope) using the methodology of Hobbie et al. (1977), as described by Danovaro and Fabiano (1995). Bacterial biovolume was estimated using an ocular micrometer (as maximal length and width) assigning bacterial cells to different size classes (Fry 1990). Subsequently, bacterial biovolume was converted into carbon content assuming $310 \mathrm{fg} \mathrm{C}_{\mu \mathrm{m}}^{-3}$ (Fry 1990). Finally, bacterial abundance and biomass were normalized to dry weight (DW) after desiccation $\left(60^{\circ} \mathrm{C}, 24 \mathrm{~h}\right)$.

\section{Organic matter}

Determination of protein concentration (PRT) was carried out according to the Hartree (1972) method, modified by Fabiano et al. (1995). The absorption was determined at $650 \mathrm{~nm}$. Bovine albumin solutions were used as standards. Carbohydrate concentration (CHO) was analyzed according to Dubois et al. (1956). The absorption was measured at $490 \mathrm{~nm}$. D(+) glucose solutions were used as standards. For each analysis, controls were performed following the same method, with sediment pre-treated at $550^{\circ} \mathrm{C}$ for $4 \mathrm{~h}$. Concentrations were expressed as $\mu \mathrm{g} \mathrm{g}^{-1}$ sediment DW.

Carbohydrate and protein concentrations were converted into carbon equivalents using the conversion factors 0.40 and $0.49 \mathrm{mg} \mathrm{C} \mathrm{mg}^{-1}$, respectively, and normalized to sediment DW (Fabiano et al. 1995).

\section{Environmental variables}

Salinity $(S)$ and temperature $(T)$ were measured at each station. A sediment sample for the measurement of the redox potential (Eh) and other environmental variables was collected at each station by inserting an additional $4.5 \mathrm{~cm}$ diameter acrylic corer to a depth of $25 \mathrm{~cm}$. Concentrations of particulate organic carbon (POC), chlorophyll- $a$ (Chl- $\alpha$ ), phaeopigment (PHP) and chlorophyll-phaeopigment equivalent (CPE) in the sediments were obtained according to standard procedures as described by Strickland and Parsons (1972), Grasshoff et al. (1983) and Parsons et al. (1984). Sediment particle size analysis used wet sieving through a $63 \mu \mathrm{m}$ mesh to separate coarse and fine fractions, according to the methods proposed by $\mathrm{Bu}-$ chanan (1984). From the sediment analysis, the median grain size (MD), the inclusive standard deviation $\left(\sigma_{1}\right)$ and the skewness $\left(s_{k}\right)$ were calculated.

\section{Analyses}

Average density values of each species identified in the macrofaunal samples, and average density values for major meiofaunal groups (nematodes, copepods, nauplii, polychaetes, ostracods, turbellarians, Tardigrada, gastrotrichs, Acarina) were calculated for each location.

An additional subset of the initial macrofauna matrix, including the information on the density values of the most abundant group (polychaetes), was also incorporated into the subsequent analyses.

Sixteen additional matrices were also constructed. In the first four matrices, density values for every faunal group (macrofauna, meiofauna, polychaetes, macroand meiofauna combined) in Collelungo beach were calculated. The other 12 matrices included information on the 4 faunal groups for each of the sampling locations.

Different diversity indices were calculated based on the 12 matrices. The following indices were used: total number of species $(S)$, total number of individuals $(N)$, Margalef's species richness $\left(d=(S-1) / \log _{e} N\right)$ and Shannon-Wiener's diversity index $\mathrm{H}^{\prime}=-\sum_{i} p_{i}\left(\log _{e} p_{i}\right)$. Equitability was assessed by Pielou's evenness index $\left(\mathrm{J}^{\prime}=\mathrm{H}_{\text {(observed) }}{ }^{\prime} / \mathrm{H}_{\max }{ }^{\prime}\right)$.

To derive similarity patterns from the faunal matrices, the Steinhaus coefficient was applied on standardized and fourth-root-transformed data. The overall multivariate biodiversity pattern was obtained from the initial matrices using two different methods: (1) by using the hierarchical agglomerative classification (Cluster), employing group-average linking (Clarke and Green 1988; Warwick and Clarke 1991), and (2) by using the nonmetric multidimensional scaling technique (nMDS) (Clarke and Warwick 1994).

The resulting multivariate patterns were compared using the methods described by Somerfield and Clarke (1995). According to the mathematical procedure they describe a rank correlation, using the harmonic rank 
correlation coefficient (Clarke and Ainsworth 1993), computed between every pair of the 16 similarity matrices produced by the 4 faunal groups. A final triangular matrix was constructed, containing the resulting values of the harmonic rank correlation coefficient. These correlation values were first of all ranked before being subjected to the second-stage MDS (Olsgard et al. 1997).

The measured environmental variables were grouped into three categories: the physicochemical variables $(\mathrm{Eh}, T, S)$, the variables relevant to food availability (TBN, Prt, Cho, POC, Chl- $\alpha$, PHP, CPE) and the variables describing sediment structure (MD, $\left.\sigma_{1}, s_{k}\right)$. Spearman's rank coefficient was used to explore whether some of the environmental variables are highly correlated with the faunal multivariate patterns. The correlation between the abiotic and biotic patterns derived from the similarity matrices and the various combinations of the environmental variables was examined using the BIO-ENV analysis (Clarke and Ainsworth 1993). To test the effect of the bacteria on the faunal assemblages the BIO-ENV analysis was performed in two modes, both with and without the total bacterial number (TBN).

\section{Results}

Community composition and abundance

The overall average density of macrofauna was 7.56 ind $\mathrm{m}^{-2}$ (individuals $\mathrm{m}^{-2}$ ) (Table 1). Polychaetes dominated the macrofaunal communities in all locations, accounting for $79.1 \%$ of the average macrofaunal density.

The overall average density of meiofauna in the 0 $10 \mathrm{~cm}$ depth was 674.3 ind $\times 10 \mathrm{~cm}^{-2}$. Nematodes $(26.7 \%)$ were co-dominant with nauplii $(27.3 \%)$ and copepods $(30 \%)$.

For the macrofauna, Mar 1-as the most natural location-revealed the greatest density, while for the meiofauna the density peak was in the eroded location Mar 2.

Bacterial density values (TBN) ranged from 26.67 to 162.78 cell $\times 10^{6} / \mathrm{g}$ sediment DW in the top $25 \mathrm{~cm}$ layer. Again, the eroded location Mar 2 showed the highest average density $\left(110\right.$ cell $\times 10^{6} / \mathrm{g}$ sediment DW).

The diversity indices (Fig. 2a-c) showed almost the same pattern for the faunal data. Number of individuals $(N)$, species richness $(d)$, Shannon's diversity $\left(H^{\prime}\right)$ and evenness $(J)$ indices, for the meiofaunal and the macro-meiofaunal-combined data, peaked in locations where the macrofauna and the polychaetes showed the lowest values. As to the total number of species $(S)$ all
Table 1 Average densities of macrofauna, meiofauna and bacteria in the three study sites (Mar 1-3) on Collelungo sandy beach

\begin{tabular}{lllll}
\hline & & Mar 1 & Mar 2 & Mar 3 \\
\hline Macrofauna & Polychaeta & 10.47 & 5.50 & 1.98 \\
& Amphipoda & 0.61 & 0.00 & 1.55 \\
& Isopoda & 0.18 & 0.00 & 0.20 \\
& Mysidacea & 0.09 & 0.00 & 0.00 \\
& Cumacea & 0.05 & 0.00 & 0.00 \\
& Oligochaeta & 0.08 & 0.59 & 1.30 \\
& Bivalvia & 0.05 & 0.00 & 0.05 \\
Meiofauna & Nematoda & 11.53 & 6.08 & 5.08 \\
& Copepoda & 276 & 300 & 175 \\
& Nauplii & 221 & 147 & 184 \\
& Polychaeta & 9 & 16 & 168 \\
& Ostracoda & 18 & 53 & 3 \\
& Turbellaria & 27 & 48 & 22 \\
& Tardigrada & 1 & 4 & 2 \\
Bacteria & Gastrotricha & 2 & 60 & 43 \\
& Acarina & 1 & 1 & 1 \\
& & 620 & 791 & 612 \\
& TBN & 60 & 110 & 87 \\
\hline
\end{tabular}

Macrofauna expressed as ind $/ \mathrm{m}^{2}$, meiofauna as ind $/ 10 \mathrm{~cm}^{2}$, and total bacterial number (TBN) as numbers of cells $\times 10^{6} / \mathrm{g}$ sediment DW

faunal groups seemed to follow the same pattern, with peaks in Station 4 for Mar 1 and Mar 3 and in Station 3 for Mar 2.

\section{Multivariate pattern}

The multivariate analyses provided additional information on the similarity pattern of community structure. Non-metric MDS and Clustering, based on the Steinhaus coefficient, drawn over a wide range of similarities, revealed almost the same patterns both for the macrobenthic species as well as for the polychaete species (Fig. 3i, ii). In these patterns, two main groups occurred: the first included most stations of the two locations Mar 1 and 2 while the second group included all stations of Mar 3; Station 3 of Mar 2 was always included in the second group. Both meiofauna and the combination of meio-macrofauna (Fig. 3iii, iv) revealed no multivariate pattern.

The multivariate patterns deriving from the three study sites are provided in Fig. 4, 5 and 6. Under the most natural conditions (Mar 1, Fig. 4) both macrofaunal and polychaete data yielded the same pattern: the two upper midlittoral stations (Stations 1, 2) are grouped together while the lower midlittoral (Station 3) and the sublittoral stations (Station 4) are well separated, located on opposite sites of the MDS plots. In the resulting plots of the meiofaunal and meio-macrofaunal-combined data, Station 3 replaces Station 1. This pattern also occurs in the cases of 
Fig. 2 Diversity indices calculated for the different faunal groups (i) macrofauna, (ii) polychaeta, (iii) meiofauna, and (iv) macromeiofauna-combined. Data for Stations 1-4 at locations Mar 1 (a), Mar 2 (b), and Mar 3 (c). $S$ total number of species, $N$ total number of individuals, $d$ Margalef's species richness, $H^{\prime}$ ShannonWiener's diversity index, $J$ Pielou's evenness index (a)

(i)



(ii)

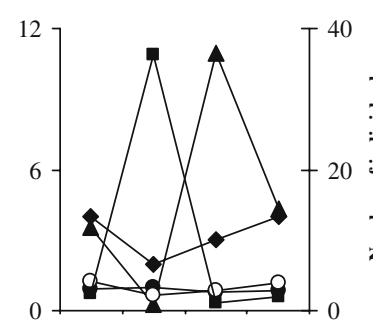

(iii)

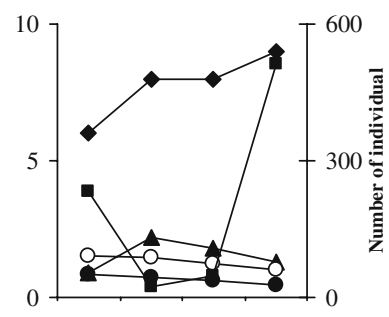

(iv)

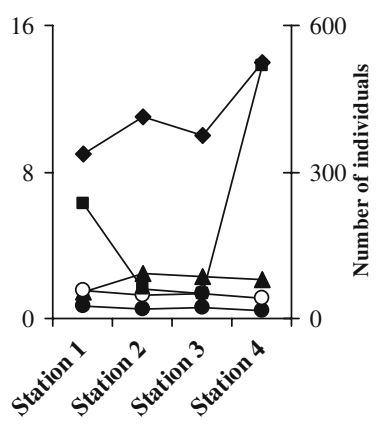

(b)
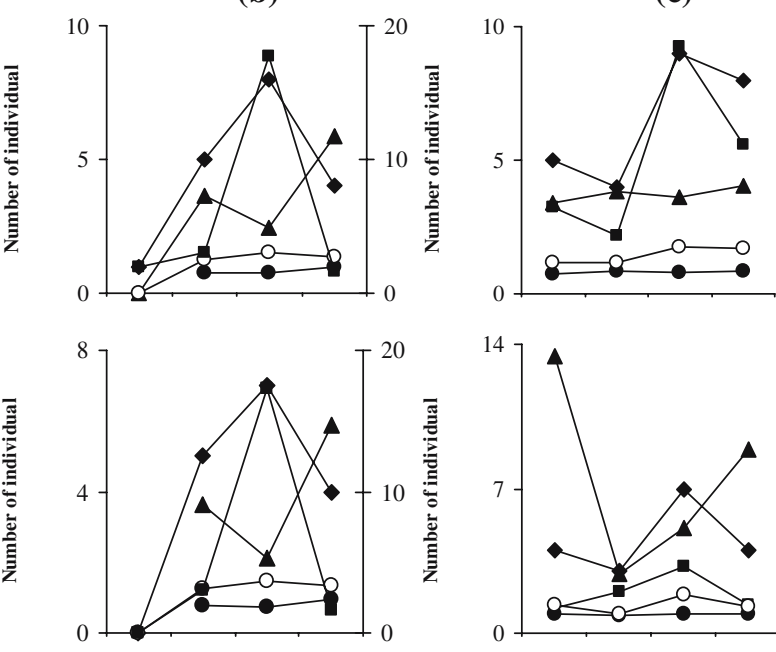

(c)

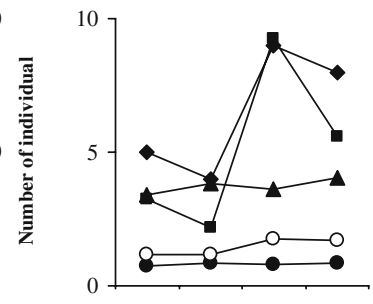

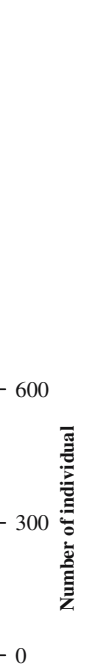
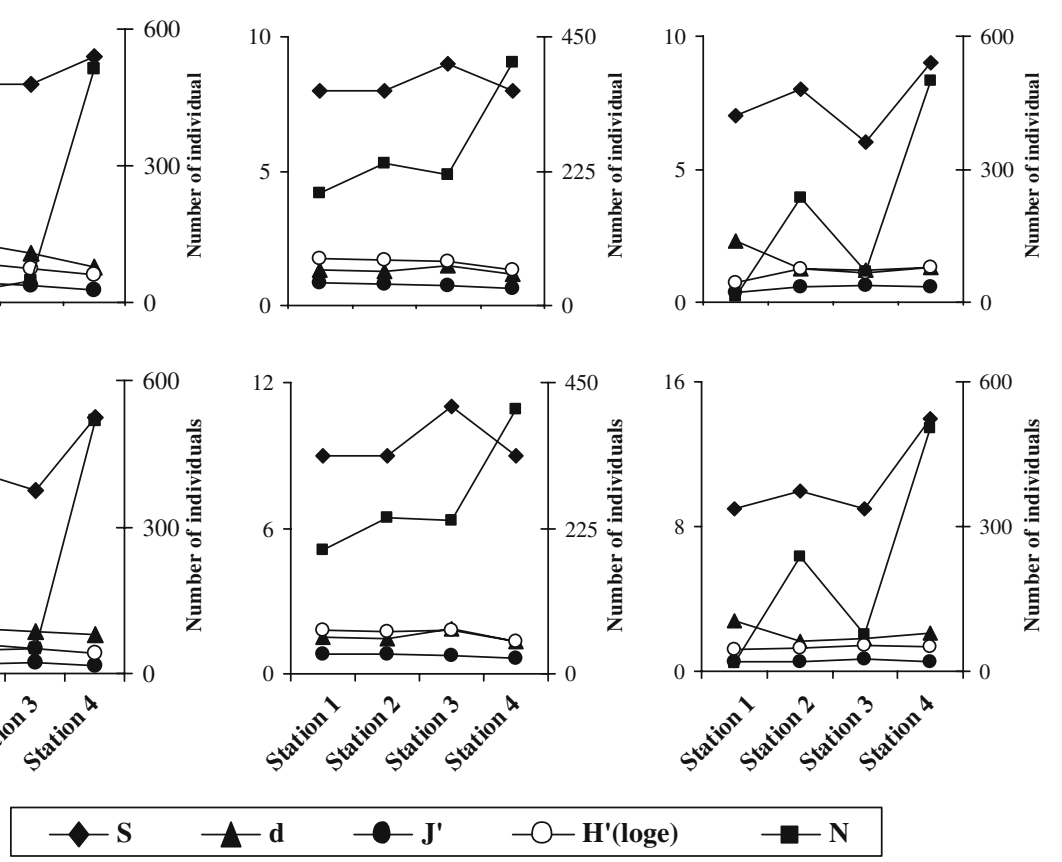

macrofaunal and meio-macrofaunal-combined data of the eroded site Mar 2, as well as in the case of meiofaunal and meio-macrofaunal-combined data in the site Mar 3. In the pattern derived from the meiofaunal data of Mar 2, the upper midlittoral station (Station 1) replaces the lower one. Finally, information on the polychaetes of Mar 3 produced no pattern; macrofaunal data of this site differentiate only the swash station (Station 2) from the remaining ones.

Macrofaunal versus meiofaunal multivariate pattern

The matrices over all study sites for macrofauna, polychaetes, meiofauna and macro-meiofauna were subjected to the Steinhaus similarity analysis. Rather than presenting the resulting MDS plots for comparison, the "second-stage" MDS procedure was adopted. The output plot where similarity matrices with similar configuration are plotted close to each other is shown in Fig. 7. There seems to be no significant change in the multivariate pattern when the information from the macrofauna is replaced by that from the polychaete taxocommunity. Conversely, the pattern derived from the meiofauna seems to deviate from that derived from the macrofauna. The pattern derived from combined meio-macrofaunal data seems to be affected by both groups as it is located between them. 
Fig. 3 Multidimensional scaling (MDS) (a) and clustering (b), based on Steinhaus similarities, for the total macrobenthic community $(i)$, the polychaete taxocommunity (ii), the meiofaunal community (iii), and for the macro-meiofaunacombined data set (iv);

Station 1, Station 2, Station 3, Station 4
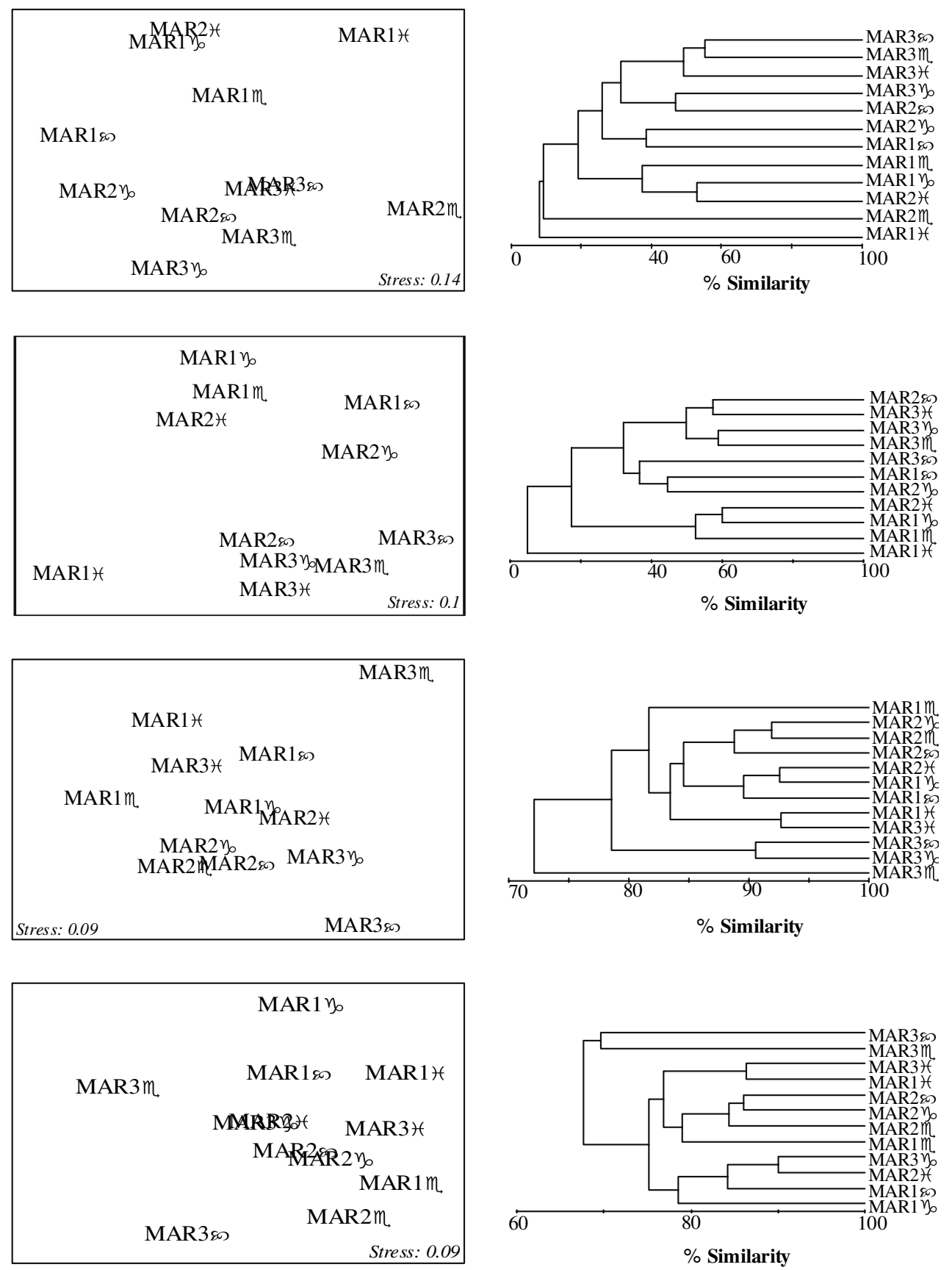

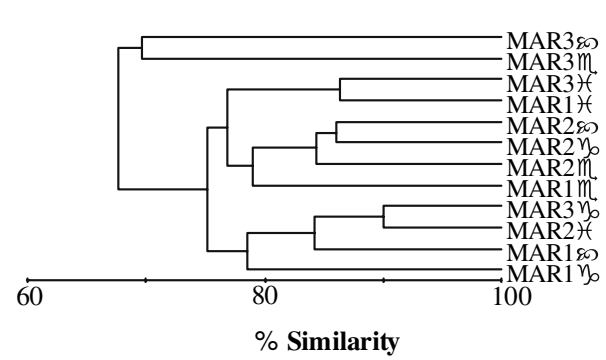

\section{Associated environmental variables}

The BIO-ENV analysis showed positively correlated $\left(\rho_{w}>0.5\right.$ for $\left.P<0.05\right)$ variables for each of the data sets. The rank correlations between environmental variables and fourth-root-transformed abundance data ranged from 0.37 to 1 (Tables 1,2 ). Similarity matrices are highly correlated with at least two of the three categories of environmental factors (physicochemical variables, food availability, sediment structure). The similarity matrices for the meiofauna seem to be more often correlated with bacteria and protein than those for the macrofauna.

\section{Discussion}

Interrelationships of meio- and macrofaunal composition patterns

Oscillations in density values of the Collelungo fauna are indicative of the extreme environment of sandy 
Fig. 4 MDS (a) and clustering (b), based on Steinhaus similarities, for stations located in Mar 1 (most natural): total macrobenthic community $(i)$, polychaete community (ii), meiofaunal community (iii), and macro-meiofaunacombined data set (iv) (a)
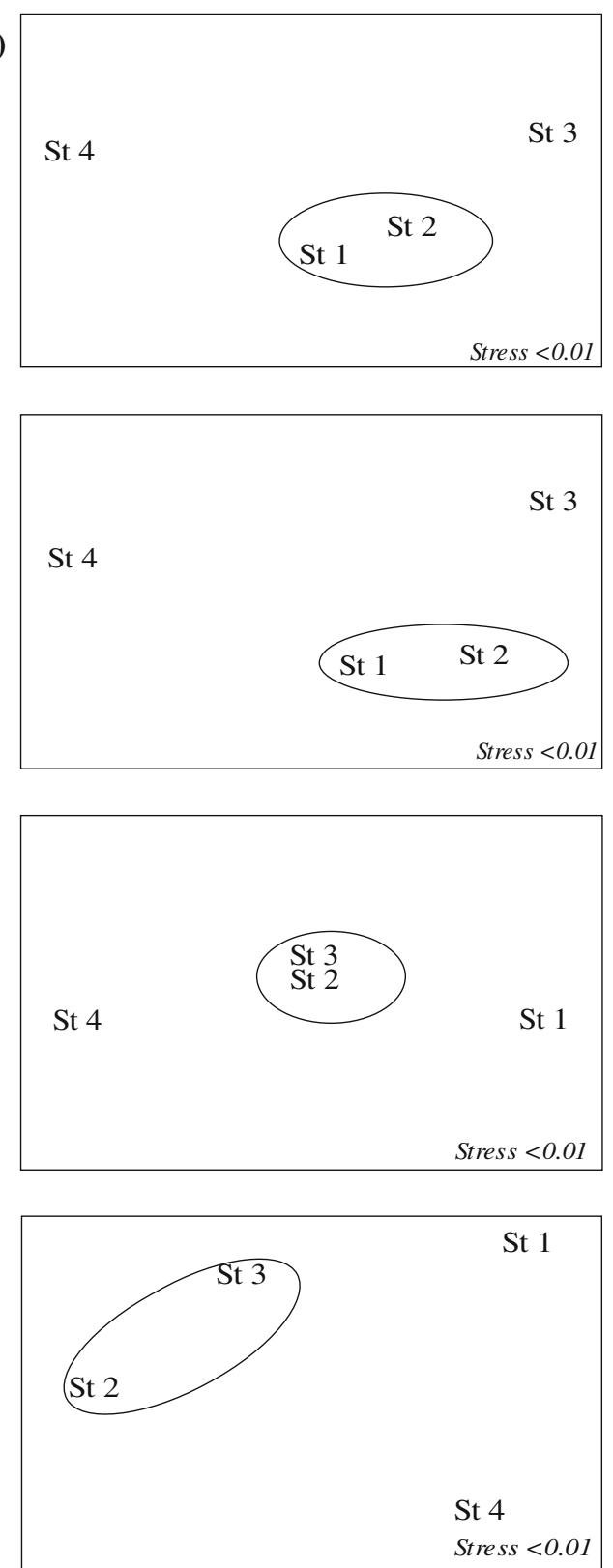

(b) St 1
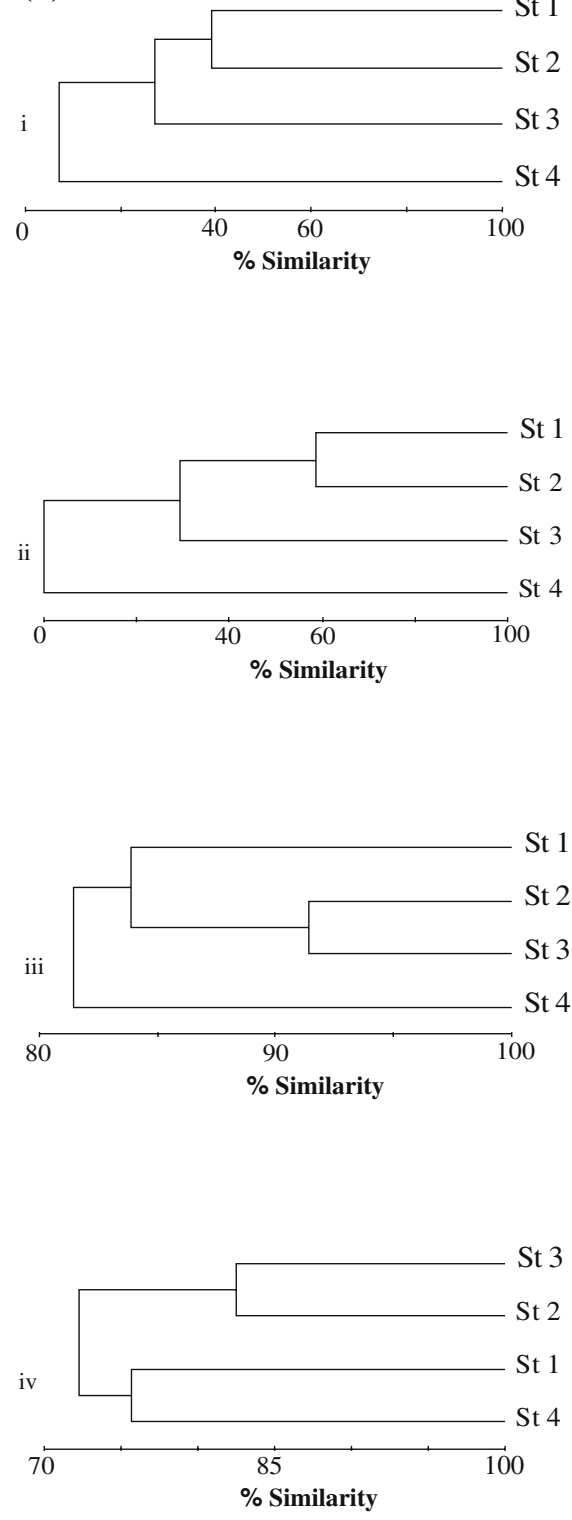

beaches (Brown and McLachlan 1990; Defeo et al. 1997). Performance of the univariate measures of diversity resulted in no distinct pattern. The application of the multivariate methods to the faunal assemblages demonstrated responses of the meio- and macrofauna to environmental pressures. According to McLachlan and Jaramillo (1995) there is a negative correlation in sandy beach ecosystems between species richness (above all macrofauna) and exposure. Mar 2 has lower macrofaunal densities and is more exposed, as indicated by its eroded character, than the other two sites. Conversely, this study site seems to be most favorable for meiofaunal organisms. Evidence from both field and laboratory studies indicates a significant increase in the meiofaunal densities in the absence of macrofauna or at low macrofaunal densities and vice versa (e.g. Bell and Coull 1978; Bell 1980; Albertelli et al. 1999).

The location Mar 3 was clearly distinguished from the other two study sites. This is possibly due to the fact that Mar 3 is affected by the Ombrone River. Additionally, multivariate techniques proved to be robust in distinguishing this site from the remaining ones, although species number and diversity values at the eroded site Mar 2 were very low. This shows a clear advantage of the multivariate techniques over the univariate measures of diversity.

In addition, the upper station (Station 1) of the midlittoral in the eroded site (Mar 2) is clearly 
Fig. 5 MDS (a) and clustering (b), based on Steinhaus similarities for stations located in Mar 2 (erosion): total macrobenthic community $(i)$, polychaete community (ii), meiofaunal community (iii), and macro-meiofauna-combined data set (iv) (a)

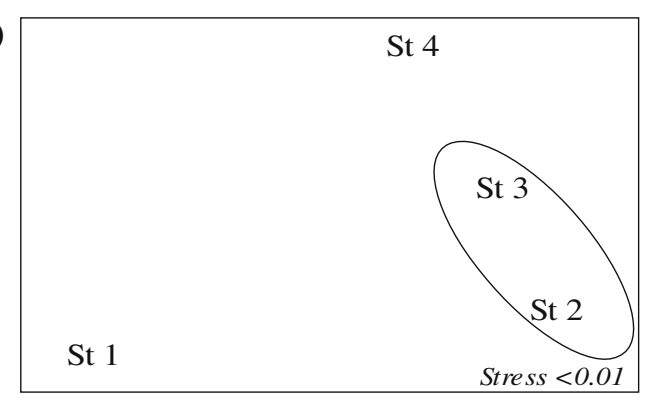

St 3
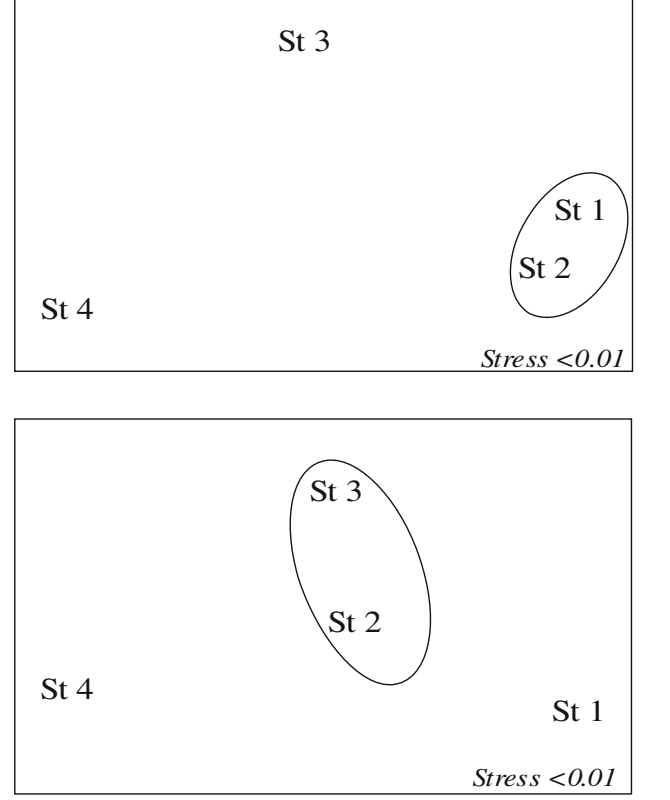

(b)
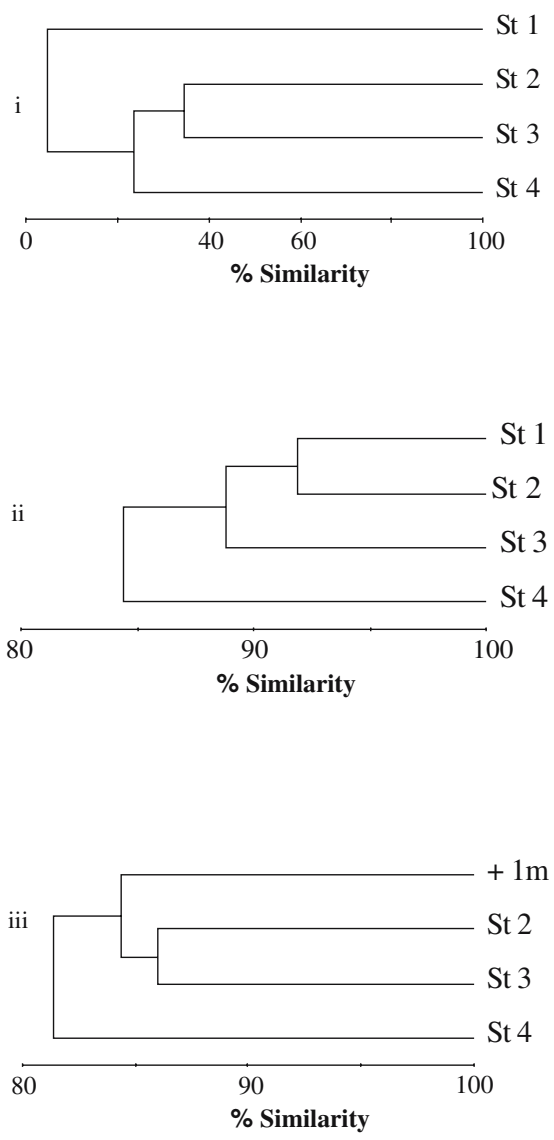

differentiated from the swash and lower midlittoral stations (Stations 2, 3). This is further indicated by the correlation of the variable $\sigma_{1}$ with the macrofaunal pattern in Mar 2, as shown by the BIO-ENV analysis. Consequently, organisms probably prefer the upper layers of the midlittoral zone, where conditions are not so severe (Brown and McLachlan 1990; Fruin 2000).

Considering the meiofaunal horizontal distribution on the beach, in Mar 1 and 3 the meiobenthic community showed a similar structure in the swash (Station 2) and in the lower midlittoral station (Station 3), while in Mar 2 the swash was closer to Station 1. The swash is considered a key area in studies dealing with benthic faunal communities of beach environments (McLachlan et al. 1995; Moreno et al. 2005b).

The results from the "second-stage" MDS showed that the similarity patterns deriving from the entire macrofaunal data set and from the polychaete data are only little different, indicating the high contribution of polychaetes to the macrobenthic community structure and their potential use as an indicator taxon for the sandy beach environment. However, the similarity with the macro-meiofauna-combined data is lower.

Bacteria and associated environmental variables

Bacterial abundance (TBN) seems to be affected by the sediment structure of the shore. In general, Stations 1 and 2 were characterized by the highest abundance values which increased from natural conditions (Mar 1) to the erosion regime (Mar 2). Ranks of the density values suggest that bacteria and meiofauna are affected in the same way by environmental variability. Meiofauna and bacteria showed high densities at Mar 2 where the macrofauna was represented by only a few individuals. The high-energy character of this site makes it an inhospitable place for macrofauna, while the microbial community is able to withstand the abrasion and sheer stress associated with a high energy environment (Novitsky and MacSween 1989).

It appears, however, that the meiofaunal pattern and TBN are highly correlated only at Mar 1 and 3, while the macrofaunal pattern and TBN are correlated only 
Fig. 6 MDS (a) and clustering (b), based on Steinhaus similarities, for stations located in Mar 3 (river discharges): total macrobenthic community $(i)$, polychaete community (ii), meiofaunal community (iii), and macro-meiofaunacombined data set (iv) (a)
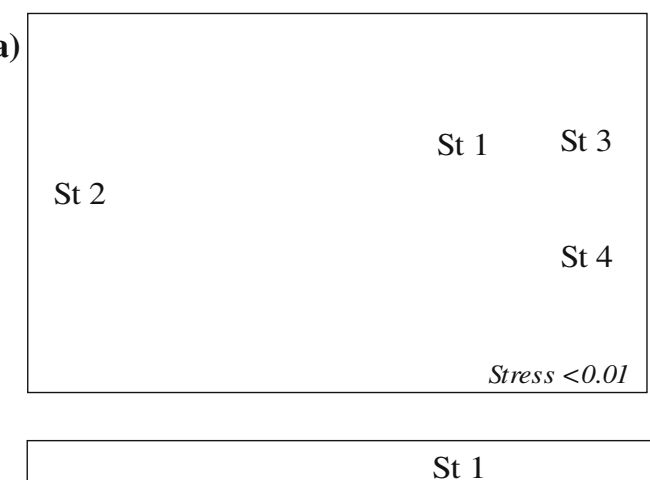

St 3

St 2

St 4

Stress $<0.01$
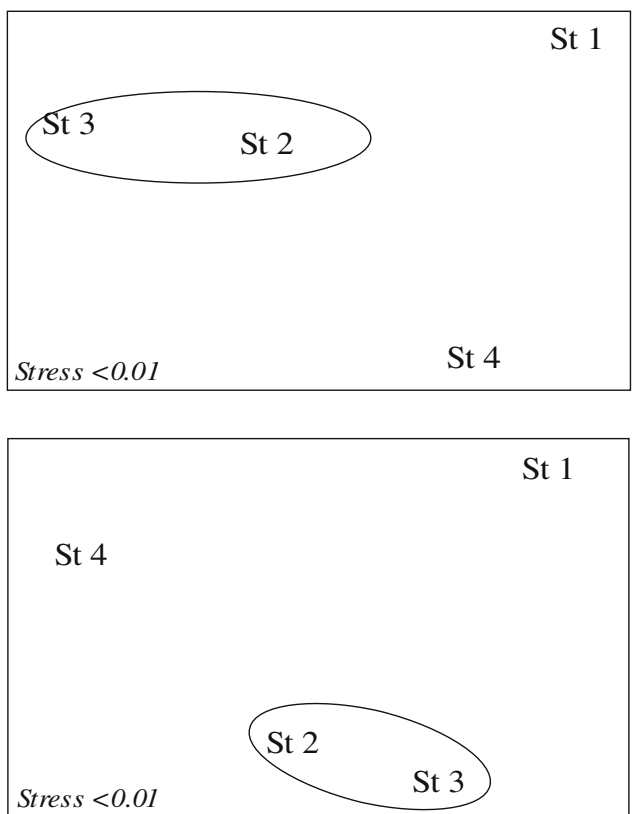

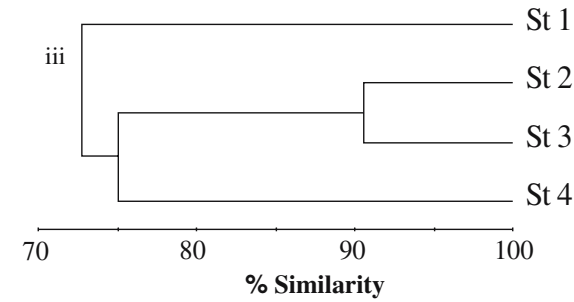

(b)
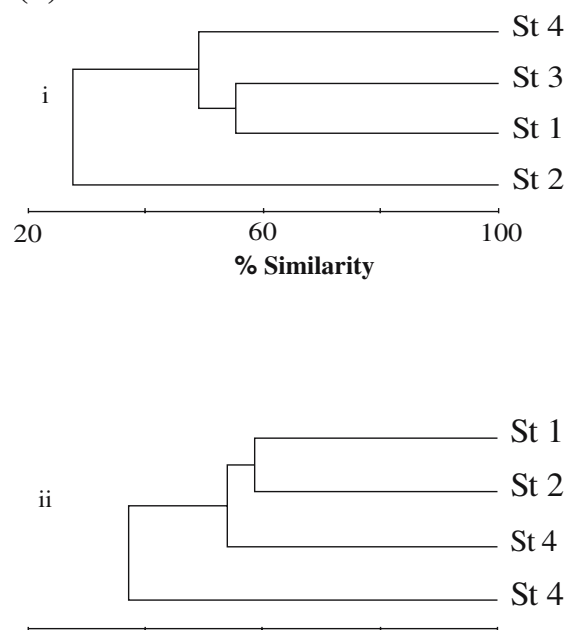

$2 \overline{0}$

$\%$ Similarity

100

1

2

St 3

St 4

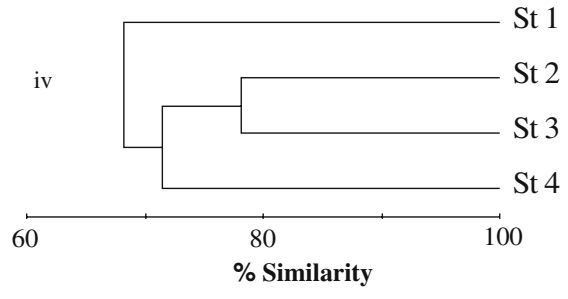

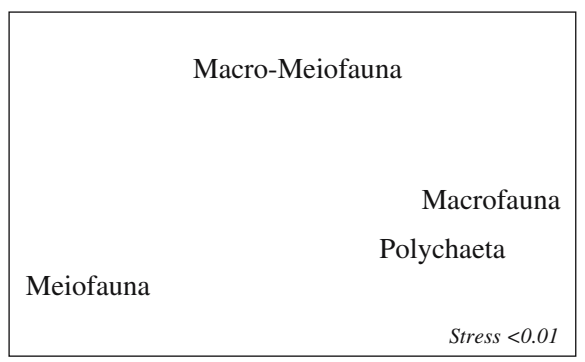

Fig. 7 Second-stage ordination nMDS comparing patterns deriving from the macrofaunal, polychaete and meiofaunal data at Mar 2. According to Sundbaeck et al. (1996) algal carbon is a more important food source for meiofauna than for bacteria, but when algal productivity is limited, meiofauna may depend on other sources such as bacteria and detritus. The low concentrations of chlorophyll- $\alpha$ and phaeopigments indicate that bacteria may be an equally important food source as microalgae for the meiofaunal community of Collelungo. This assumption is supported by the fact that the meiofaunal pattern is also strongly correlated with Chl- $\alpha$, POC and CPE. 
Table 2 Environmental variables best correlated with the similarity pattern of the faunal assemblages

(a) Total bacterial number included

\begin{tabular}{|c|c|c|c|c|c|c|c|c|c|c|c|c|c|c|}
\hline & & $T$ & $S$ & Eh & Chl- $a$ & PHP & POC & MD & $\sigma_{1}$ & $s_{k}$ & Prt & Cho & $\mathrm{TBN}$ & $\rho_{w}$ \\
\hline \multirow[t]{4}{*}{ All samples } & Macrofauna & & & & + & & & & & & & & & 0.536 \\
\hline & Meiofauna & + & + & & & & + & & + & & & + & & 0.656 \\
\hline & Macro-Meiofauna & + & & & & + & + & & + & & & + & & 0.502 \\
\hline & Polychaeta & & & & + & & & & & & & & & 0.675 \\
\hline \multirow[t]{4}{*}{ Mar 1} & Macrofauna & + & & + & + & + & + & + & + & & & + & & 1.000 \\
\hline & Meiofauna & + & + & + & + & & + & + & + & & & + & + & 1.000 \\
\hline & Macro-Meiofauna & & + & + & + & & & & + & & & + & & 0.829 \\
\hline & Polychaeta & + & & + & + & + & + & & + & & & + & & 0.941 \\
\hline \multirow[t]{4}{*}{ Mar 2} & Macrofauna & + & & & & + & & & + & & + & + & + & 0.928 \\
\hline & Meiofauna & + & + & + & + & + & + & + & + & & & & & 0.943 \\
\hline & Macro-Meiofauna & + & & + & + & + & + & & & + & & + & & 1.000 \\
\hline & Polychaeta & + & & + & + & + & + & + & + & + & + & & & 1.000 \\
\hline \multirow[t]{4}{*}{ Mar 3} & Macrofauna & & & & + & & + & & & + & & & & 0.943 \\
\hline & Meiofauna & + & & + & & & + & + & & & & & + & 1.000 \\
\hline & Macro-Meiofauna & + & & & & & + & & & & & & & 0.829 \\
\hline & Polychaeta & & & & & & + & & & + & + & & & 0.371 \\
\hline
\end{tabular}

(b) Total bacterial number not included

\begin{tabular}{|c|c|c|c|c|c|c|c|c|c|c|c|c|c|}
\hline & & $T$ & $S$ & $\mathrm{Eh}$ & Chl- $a$ & PHP & POC & MD & $\sigma_{1}$ & $s_{k}$ & Prt & Cho & $\rho_{w}$ \\
\hline \multirow[t]{4}{*}{ All samples } & Macrofauna & & & & + & & & & & & & & 0.527 \\
\hline & Meiofauna & + & & & & & + & & + & & + & + & 0.624 \\
\hline & Macro-Meiofauna & + & & & & + & + & & + & & + & + & 0.499 \\
\hline & Polychaeta & & & & + & & & & & & & & 0.690 \\
\hline \multirow[t]{4}{*}{ Mar 1} & Macrofauna & & & + & + & + & + & & + & & & + & 1.000 \\
\hline & Meiofauna & + & & & + & & & & + & & + & + & 0.943 \\
\hline & Macro-Meiofauna & & + & & & & & & & & & + & 0.886 \\
\hline & Polychaeta & + & & + & + & & + & + & + & & & + & 0.941 \\
\hline \multirow{4}{*}{ Mar 2} & Macrofauna & + & & & & + & & & + & & & + & 0.696 \\
\hline & Meiofauna & + & + & & & + & & & + & & & & 1.000 \\
\hline & Macro-Meiofauna & + & & + & & + & + & & & + & & + & 1.000 \\
\hline & Polychaeta & + & + & + & + & + & & & + & & + & & 1.000 \\
\hline \multirow[t]{4}{*}{ Mar 3} & Macrofauna & & + & & & + & & & & + & & + & 0.886 \\
\hline & Meiofauna & + & & + & & & + & & + & & + & & 1.000 \\
\hline & Macro-Meiofauna & + & + & + & & & + & + & + & & + & & 0.600 \\
\hline & Polychaeta & & & + & & + & + & & + & + & & + & 0.429 \\
\hline
\end{tabular}

$T$ sediment temperature, $S$ salinity, $E h$ redox-potential, $C h l-\alpha$ chlorophyll $\alpha$ concentration, $P H P$ phaeopigments concentration, $C P E$ chloroplastic pigment equivalent, $P O C$ particulate organic carbon concentration, $M D$ median grain size, $\sigma_{1}$ inclusive graphic standard deviation, $s_{k}$ skewness coefficient, Prt proteins, Cho carbohydrates, $T B N$ total bacteria number, $\rho_{w}$ harmonic rank coefficient

For Mar 2 the correlation of macrofauna with TBN, proteins and phaeopigments in combination with the low concentrations of Chl- $\alpha$, POC, carbohydrates and the high densities of bacteria and meiofauna indicate the dependence of the macrofauna on bacteria as a food source in such extreme conditions. Consequently, the macrofauna appears to compete with meiofauna for food resources. Both organic matter and associated microorganisms constitute food for the deposit feeders (Gray 1981; Tsutsumi et al. 1990). Indeed, the most abundant species, such as the polychaetes Ophelia bicornis, O. radiata, Ctenodrilus serratus, Scolelepis squamata and $S$. mesnili, are commonly considered as deposit feeders (Rouse and Pleijel 2001).
The BIO-ENV analysis without the TBN variable showed again the faunal dependence on food sources. The parameters associated with food availability such as Chl- $\alpha$, POC, protein and carbohydrate concentrations are best correlated with most of the faunal data. The physicochemical variables, mostly represented by the temperature and the redox potential, also seem to affect the faunal pattern to a great extent. Finally, the sediment structure $\left(\sigma_{1}\right)$ is important for the faunal assemblages.

From the above-mentioned results, it is clear that the sandy beach faunal communities are affected synergistically by many abiotic factors (Brown 1971; Eleftheriou and Nicholson 1975). This finding is in 
accordance with the multicausal environmental severity hypothesis, which admits that species with different characteristics are controlled by different limiting factors (Brazeiro 2001). Taxon-specific responses to environmental variables may well be the reason for the different patterns revealed by the multivariate analyses.

Acknowledgments Parts of this study were supported by the MEDCORE Project, funded by the EU CICA3-CT-2002-10003. The authors wish to acknowledge Mrs Margaret Eleftheriou for the critical reading of the manuscript.

\section{References}

Albertelli G, Covazzi-Harriague A, Danovaro R, Fabiano M, Fraschetti S, Pusceddu A (1999) Differential responses of bacteria, meiofauna and macrofauna in a shelf area (Ligurian Sea, NW Mediterranean): role of food availability. J Sea Res 42:11-26

Bell SS (1980) Meiofauna-macrofauna interactions in a high salt marsh habitat. Ecol Monogr 50:487-505

Bell SS, Coull BC (1978) Field evidence that shrimp predation regulates meiofauna. Oecologia 35:141-148

Brazeiro A (2001) Relationship between species richness and morphodynamics in sandy beaches: what are the underlying factors? Mar Ecol Prog Ser 224:35-44

Brown AC (1971) The ecology of the sandy beaches of the Cape Peninsula, South Africa. Part 1: Introduction. Trans Roy Soc S Afr 39:247-279

Brown AC, McLachlan A (1990) Ecology of sandy shores. Elsevier, Amsterdam

Buchanan JB (1984) Sediment analysis. In: Holme NM, McIntyre AD (eds) Methods for the study of marine benthos. Blackwell Scientific, Oxford, pp 41-64

Clarke KR, Ainsworth M (1993) A method for linking multivariate community structure to environmental variables. Mar Ecol Prog Ser 92:205-209

Clarke KR, Green RH (1988) Statistical design and analysis for a "biological effects" study. Mar Ecol Prog Ser 46:213-226

Clarke KR, Warwick RM (1994) Change in marine communities: an approach to statistical analysis and interpretation. Natural Environmental Research Council, Plymouth Marine Laboratory, Plymouth

Danovaro R, Fabiano M (1995) Seasonal and interannual variation of benthic bacteria in a seagrass bed of the Mediterranean Sea: relationship with labile organic compounds and other environmental factors. Aquat Micr Ecol 9:17-26

Defeo O, Brazeiro A, de Alava A, Riestra G (1997) Is sandy beach macrofauna only physically controlled? Role of substrate and competition in Isopods. Estuar Coast Shelf Sci 45:3-462

Dubois M, Gilles K, Hamilton JK, Rebers PA, Smith F (1956) Colorimetric method for determination of sugars and related substances. Anal Chem 28:350-356

Eleftheriou A, Nicholson MD (1975) The effects of exposure on beach fauna. Cah Biol Mar 16:695-710

Fabiano M, Danovaro R, Fraschetti S (1995) A three-year time series of elemental and biochemical composition of organic matter in subtidal sandy sediments of the Ligurian Sea (NW Mediterranean). Cont Shelf Res 15:1453-1469
Fabiano M, Marin V, Misic C, Moreno M, Salvo VS, Vezzulli L (2004) Sedimentary organic matter and bacterial community in microtidal mixed beaches of the Ligurean Sea (NW Mediterranean). Chem Ecol 20:423-435

Fry JC (1990) Direct methods and biomass estimation. In: Grigorova R, Norris JR (eds) Methods in microbiology, vol 22. Academic Press, New York, pp 41-85

Fruin P (2000) Effects of anthropogenic disturbances of tropical soft-bottom benthic communities. Mar Ecol Prog Ser 194:39-53

Grasshoff K, Ehrhard M, Kremmling K (1983) Methods of seawater analysis. Verlag Chemie, Berlin

Gray JS (1981) The ecology of marine sediments. An introduction to the structure and function of benthic communities. Camb Stud Mod Biol 2:1-185

Hartree EF (1972) Determination of proteins: a modification of the Lowry method that give a linear photometric response. Anal Biochem 48:422-427

Heip C, Vinx M, Vranken G (1985) The ecology of marine nematodes. Oceanogr Mar Biol Annu Rev 23:399-489

Higgins RP, Thiel H (1988) Introduction to the study of meiofauna. Smithsonian Institution Press, Washington

Hobbie JE, Daley RJ, Jasper S (1977) Use of Nuclepore filters for counting bacteria by fluorescence microscopy. Appl Environ Microbiol 33:1225-1228

Incera M, Cividanes SP, Lastra M, Lopez J (2003) Temporal and spatial variability of sedimentary organic matter in sandy beaches on the northwest coast of the Iberian Peninsula. Estuar Coast Shelf Sci 58:55-61

Jedrzejczak MF (2002) Stranded Zostera marina L. vs wrack fauna community interactions on a Baltic sandy beach $(\mathrm{Hel}$, Poland): a short-term pilot study. Part I. Driftline effects of fragmented detritivory, leaching and decay rates. Oceanologia 44:273-286

Koop K, Griffiths L (1982) The relative significance of bacteria, meio- and macrofauna on an exposed sandy beach. Mar Biol 66:295-300

Kotwicki L, De Troch M, Urban-Malinga B, Gheskiere T, Weslawsky JM (2005) Horizontal and vertical distribution of meiofauna on sandy beaches of the North Sea (The Netherlands, Belgium, France). Helg Mar Res 59:255-264

Marques JC, Goncalves SC, Pardal MA, Chelazzi L, Colombini I, Fallaci M, Bouslama MF, ElGtari M, Charfi-Cheikhrouha F, Scapini F (2003) Comparison of Talitrus saltator (Amphipoda, Talitridae) biology, dynamics, and secondary production in Atlantic (Portugal) and Mediterranean (Italy and Tunisia) populations. Estuar Coast Shelf Sci 58:127-148

McLachlan A, Jaramillo E (1995) Zonation on sandy beaches. Oceanogr Mar Biol Annu Rev 33:305-335

McLachlan A, Jaramillo E, Defeo O, Dugan J, de Ruyck A, Coetzee P (1995) Adaptations of bivalves to different beach types. J Exp Mar Biol Ecol 187:147-160

Moreno M, Granelli V, Albertelli G, Fabiano M (2005a) Meiofaunal distribution in microtidal mixed mixed beaches of the Ligurian Sea (NW Mediterranean). Meiofauna Mar 14:131-137

Moreno M, Ferrero TJ, Granelli V, Marin V, Albertelli G, Fabiano M (2005b) Across shore variability and trophodynamic features of meiofauna in microtidal beach of the NW Mediterranean. Estuar Coast Shelf Sci 66:357-367

Novitsky JA, MacSween MC (1989) Microbiology of a high energy beach sediment: evidence for an active and growing community. Mar Ecol Prog Ser 52:71-75

Olsgard F, Somerfield PJ, Carr MR (1997) Relationships between taxonomic resolution and data transformations in 
analyses of a macrobenthic community along an established pollution gradient. Mar Ecol Prog Ser 149:173-181

Parsons TR, Maita Y, Lali CM (1984) A manual of chemical and biological methods for seawater analysis. Pergamon, New York

Rouse G, Pleijel F (2001) Polychaetes. Oxford University Press, Oxford, p 364

Somerfield PJ, Clarke KR (1995) Taxonomic levels, in marine community studies, revisited. Mar Ecol Prog Ser 127:113119

Strickland JD, Parsons TR (1972) A practical handbook of seawater analysis. Bull Fish Res Board Canada 167:1-310

Sundbaeck K, Nilsson P, Nilsson C, Joensson B (1996) Balance between autotrophic and heterotrophic components and processes in microbenthic communities of sandy sediments: a field study. Estuar Coast Shelf Sci 43:689-706

Tsutsumi H, Fukunaga S, Fujita N, Sumida M (1990) Relationship between growth of Capitella sp. and organic enrichment of the sediment. Mar Ecol Prog Ser 63:157-162

Turner SJ, Thrudh SF, Pridmore RD, Hewitt JE, Cummings VJ, Maskery M (1995) Are soft-sediment communities stable? An example from a windy harbour. Mar Ecol Prog Ser 120:219-230

Warwick RM, Clarke KR (1991) A comparison of some methods for analyzing changes in benthic community structure. J Mar Biol Ass UK 71:225-244 